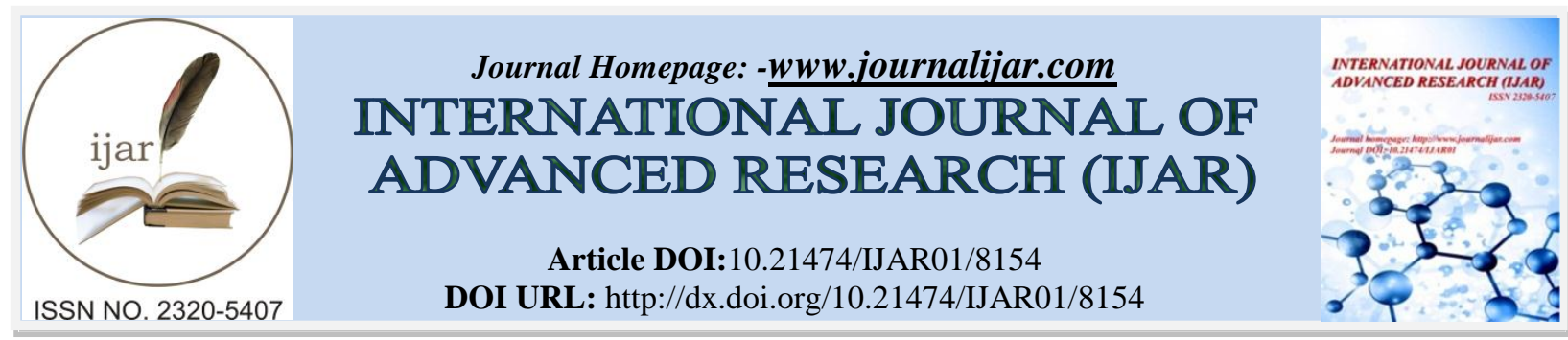

RESEARCH ARTICLE

\title{
THE EFFECT OF CORPORATE REPUTATION AND WOMAN DIRECTOR ON CORPORATE FINANCIAL PERFORMANCE AS MODERATED NARCISSISM EXECUTIVE.
}

\author{
NurAzisah Syam ${ }^{1}$, Yohanis Rura ${ }^{2}$ and Darwis Said ${ }^{2}$. \\ 1. Master of Accounting, Hasanuddin University, Indonesia. \\ 2. Economics and Business Faculty, Hasanuddin University, Indonesia.
}

\section{Manuscript Info}

\section{Manuscript History}

Received: 04 October 2018

Final Accepted: 06 November 2018

Published: December 2018

Keywords:-

self-efficacy, obedience pressure, task complexity, moral reasoning, audit judgment.

\begin{abstract}
This study aims to determine the effect of corporate reputation and woman director on corporate financial performance moderated by narcissism executive. The sample of this study was 114 companies listed on the Indonesia Stock Exchange and has an excellent value from IMAC. Research data uses annual reports and CII during the 2015-2017 period obtained from Indonesian Capital Exchange (IDX) and Indonesian Corporate Image Award (IMAC). Data analysis uses analysis of Moderated Regression Analysis (MRA). The results show that (1) corporate reputation has a positive effect on corporate financial performance, (2) woman director has a negative effect on the corporate financial performance, (3) narcissism executive positive effect on corporate financial performance, (4) narcissism executive can moderate the effects of corporate reputation on corporate financial performance, (5) narcissism executives can moderate the effects of woman director on corporate financial performance. The implications of the research are that this research is expected to give benefits to companies and investors, especially on the effect of corporate reputation and woman director on the corporate financial performance as moderated by narcissism executive. This research empirically can be used as reference material for policy making and decisions by company management and investors.
\end{abstract}

Copy Right, IJAR, 2018,. All rights reserved.

\section{Introduction:-}

The more rapid economic growth in the current era of globalization makes business people compete to the best. This is done to attract stakeholder attention, for the sake of long-term business sustainability, especially for large companies that have entered the capital market. One measure of stakeholder assessment of the success of a company in managing finances is by looking at the corporate financial performance. Information on financial performance can a consideration for investors (to invest) and creditors (to provide loans to companies).

It is so important to pay attention to the assessment of financial performance, so that if a decline or a problem in the corporate financial performance will have an impact on the reaction of stakeholders. As in the case of the Lippo Group company reported by Katadata online newspaper which reported a decline in the majority share price on the Indonesia Stock Exchange (IDX). The decline in sales has a direct impact on the company's net profit. In addition, there was a similar case that occurred in 2014 which explained that the share price of issuers based on animal feed 
and poultry weakened. This weakening due to the company's net profit in this sector fell sharply in the third quarter of 2014.

The two cases above illustrate how important it is to maintain the stability of the corporate financial performance. Not only seen from financial factors, but non-financial factors also need to be reviewed. Like a corporate reputation as an intangible asset because it can distinguish one company from another, it means that a company that has a reputation will be difficult to imitate by competitors and can be successfully translated as a competitive advantage. Famous companies can take advantage of their reputation and additional premium costs for their products and / or services because they are considered better on the market (Rindova et al. 2005).

This phenomenon is supported by research conducted by Robert and Grahame (2002) which states that companies with a relatively good reputation are able to maintain superior earnings results over time. Many organizations consider their greatest asset to be their name or good reputation. This phenomenon is supported by research conducted by Robert and Grahame (2002) which states that companies with a relatively good reputation are able to maintain superior earnings results over time. Many organizations consider their greatest asset to be their name or good reputation. This is especially true in knowledge-based organizations such as professional service companies in the consulting sector, law, medical, and finance.

In addition to the corporate reputation, the board of directors and commissioners of the company also need to be explored because the boards of directors and commissioners are the highest part of an organization that has important involvement in strategy and making the right decisions for the company. Discussion of variations in leadership has become a widely discussed topic lately, especially with regard to gender, where woman directors has become a consideration to join the leadership in company. The diversity of the board of directors and commissioners, especially the gender diversity found in the company is still a matter of debate. As explained by Smith, et al. (2006) that diversity can improve problem solving and decision making because the diversity of perspectives that emerge from a more diverse board means that more alternatives are evaluated.

This is supported by research by Huang and Kisgen (2013) found that woman can change the situation of boardrooms because women are more careful than men in making corporate decisions. In addition, Adams and Ferreira (2009) examined 1500 companies in the United States from 1996-2003 and found woman directors had a significant impact on company performance. They stated that woman directors were more likely to monitor their committees. However, unfortunately the theoretical and empirical evidence to support this statement is still inconclusive where some of the research that has been carried out with regard to the existence of women in company directors has so far yielded different results. As Dobbin and Jung (2011) stated, the relationship between woman directors and U.S. corporate financial performance found evidence of a negative correlation between gender board diversity and Tobin's Q, but there was no significant relationship between gender diversity and Return on Assets (ROA).

Besides that the psychological characteristics of the board of directors and commissioners are also important to know, especially to account for decisions that have been made. Psychological characteristics are important for the success of executive managers in their work. One of the psychological characteristics that can be seen from the board of directors and commissioners is the nature of narcissism. This is because organizations are basically run by humans, performance appraisals are actually an assessment of human behavior in carrying out the roles they play in the organization (Mulyadi, 2001: 420). Narcissistic people need an affirmation of their increased self-confidence. They need positive feedback, praise, and recognition. The accounting report, especially income can function as a tool to achieve the satisfaction of the board of directors and commissioners. The results of published profits are given as a single number such as Earning Per Share, which is reported three months and every year, it seems that it is possible for narcissistic CEOs to fulfill their needs for frequent confirmation and applause (Amernic and Craig, 2010).

Variable narcissism executive in this study was inspired by research conducted by Olsen (2011) who examined CEO Narcissism and accounting. Olsen's (2011) study uses the superiority of CEO photos in the company's annual report to measure narcissism CEO, this is done because the superiority of CEO photos as a measure that is not conspicuous for narcissistic personality tendencies, meaning using photo excellence, the CEO will not show his narcissism directly. The more prominent photos in the annual report are likely to attract attention and encourage the recognition of the board of directors and commissioners who are narcissistic. The results of his research show that there is a 
positive relationship between CEO narcissism and accounting as measured by looking at Earning per share of the company.

The difference between this research and previous research is that in the variable narcissism executive which is a moderating variable, where previous research only examined the direct relationship of the independent variable to the dependent variable. Based on these explanations, the researcher is interested in seeing the influence of corporate reputation and woman director on financial performance moderated by narcissism executive.

\section{Literature Review and Hypotheses:- Signalling Theory:-}

Akerlof (1970) assumes that in the used car market, there are cars that are "lemon" items and those that have good quality. The parable of lemon means that the item looks good outside like a lemon peel, but inside it is of poor quality like lemon acid. This lemon problem can be investigated using two types of information carried on the market namely asymmetric information and symmetrical information. The idea of Akerlof (1970) was developed by Morris (1987) which states that signaling theory is relevant to explain the problem of information asymmetry between companies and potential investors.

Signaling theory examine the problem of information asymmetry in the market. This theory shows how this asymmetry can be reduced by more information that signals others. Suppose by providing information about the superior quality of their products to buyers and thus increasing the price. This means that the company intentionally signals the market, which the market is expected to react to and influence the company's stock price which will also affect the corporate financial performance. This is because the company's executives have better information about the company will be motivated to convey this information to prospective investors so that the company's stock price increases (Ross 1977).

\section{Resource Dependency Theory:-}

Resource dependency theory focuses on external relations with power held by the most important divisions to overcome and solve organizational problems arising from the surrounding environment (Pfeffer and Salancik, 1978). Hillman, et al. (2000) argue that the diversity of the board will provide various benefits of resources for the company. So that a more diverse board will provide more valuable resources, which should result in better company performance. Gender differences in the board of commissioners and the board of directors are also very possible to produce unique information available to management that is used in better decision making.

When applying resource dependency theory to examine the gender impact of diverse board of directors on corporate financial performance, the following aspects arise: first, in view of resource dependence, woman directors bring a variety of valuable resources to the board. According to Terjesen, et al (2009), woman directors included knowledge, skills and experience to their councils that were different from their male counterparts. Furthermore, woman directors have the ability to create links with various parties rather than men, for example to different customers, suppliers, employees or future suppliers (Hillman, et al., 2007).

\section{Motivation Theory - Self Actualization Maslow:-}

The best theory of motivation that is known is the hierarchy of needs theory of Abraham Maslow. Maslow hypothesizes that in every human being there is a hierarchy of five needs (Robbins and Timothy, 2015: 128). The need for self-actualization is a necessity in the highest hierarchy in Maslow's theory which explains the need to experience self-fulfillment. These needs include the need to develop the potential that exists in oneself as a whole, improve one's ability, and become a better person.

Maslow (1948) states that the concept of actualization can be related in terms of motivation levels and personality syndromes. This is done by stating that the need for gratification is the center of character formation. Individuals at different motivational levels are thus assumed to be different in terms of psychological health, or 'health gratification'. In this case, it can be said that self-actualization does not only refer to individual quality but also the quality of the relationship a person has with the world (Daniels, 1982).

\section{Corporate Reputation:-}

Reputation is a (intangible) assets and creates obstacles to competitive threats. An established reputation inhibits competitive mobility and results in returns to the company because it is difficult to replicate. The strong corporate 
reputation shows that the products and services offered by the company have higher quality (Carmeli and Tishler, 2005). The reputation of a company emerges as an intangible asset that distinguishes a company from others and attracts customers to repurchase and is willing to pay higher prices for products (Eberl and Schwaiger, 2005).

Lee and Jungbae (2012) who stated that variables such as corporate reputation were significantly and positively related to most of the corporate financial performance index. Similar research has also been conducted by Roberts and Grahame (2002) which shows that companies with a relatively good reputation are able to maintain superior earnings results over time. Kitchen and Andrew (2003) also show that corporate reputation has a significant meaning, especially for managers, so that it helps maintain business in national, international and global performance. A business can achieve its goals more easily if it has a good reputation among its stakeholders, especially key stakeholders such as its biggest customers, opinion leaders in the business community, suppliers and employees today and has the potential (Dunn and Schweitzer, 2005).

\section{Woman Director:-}

There are several reasons to anticipate that women's participation in the boards of developing market companies will have a positive impact on accounting performance. First, women's excellence in building relationships and in collaborative work is very valuable for group work that characterizes board activities (Dargnies, 2012). Women also tend to excel at monitoring activities and asking management to responsible for better performance than men (Triana, et al, 2014). In addition, advisory roles can enhanced by the presence of larger women, because their different backgrounds, perspectives, and problem solving skills give top managers the best advice and advice (Anderson, et al, 2011).

According to Abdullah et al. (2015) attributes of various ethnic councils tend to accentuate the positive impact of women's councils on accounting performance. Shareholders tend to believe that ethnically diverse councils pay more attention to diverse needs and better protect their interests, and therefore view gender diversity well by the board.

Hillman et al. (2007) found that woman directors have the ability to create relationships with various parties rather than men, for example to different customers, suppliers, employees or future suppliers. This is supported by Carter et al. (2003) who examined how the proportion of women and individuals from different ethnic groups affected the corporate financial performance, as measured by Tobin's Q, and based on data from the Fortune 100 list, they found that companies with at least two female directors have better performance. Tarr-Whelan (2009) also argues that companies with a higher proportion of women in senior positions have higher profits and greater ability to withstand financial downturns.

The presence of women on the board of directors increases the diversity of functional backgrounds. Board diversity tends to be of special value in emerging markets, because it reflects the high level of diversification typical of emerging market companies. Pfeffer and Salancik (1978) suggest that diverse companies are subject to the demands of diverse and diverse environments so that they require a variety of capabilities to manage them.

\section{Narcissism Executive and Financial Performance:-}

According to Kets and Manfred (1994), narcissism influences major leadership activities, including environmental scanning, decision making, and relationships with subordinates. To support grandiose self-perception and to attract external attention, narcissistic leaders tend to advocate for large organizational plans (Lubit, 2002). When CEOs have a higher level of narcissism, they tend to strive for brave, courageous actions that increase their stature by drawing attention to their vision and leadership (Judge et al., 2009). Furthermore, narcissists are driven by extraordinary desire to compete (Maccoby, 2004).

People with high levels of narcissism "are experts at creating ways to get what they need: there is positive feedback and seducing others" (Young and Pinsky, 2006). When CEOs have a higher level of narcissism, they tend to strive for brave, courageous actions that increase their stature by drawing attention to their vision and leadership (Judge et al., 2009). Olsen (2011) who examined the relationship between the tendency of narcissistic personality of CEOs in Fortune 500 companies and accounting found a positive relationship between CEO narcissism and Earnings PerShare. Likewise research conducted by Wales, et al. (2013) which states that its findings offer a better understanding of how narcissistic CEOs affect performance variance, and why companies they lead can sometimes 
even be seen as a path to success. In addition, in Chatterjee and Hambrick's (2007) study found CEO narcissism was positively related to financial performance as measured by looking at shareholder returns and ROA.

People who have obtained executive positions certainly have fulfilled the physiological needs of "social" security and self-esteem so that they are at the stage of self-actualization needs. Actualization needs describe someone to reach their best potential. This supports the narcissism executive variable relationship with the company's financial performance.

Based on the correlation of theory and previous research, the hypotheses to tested in this study are as follows.

H1: Corporate reputation has a positive effect on corporate financial performance.

$\mathrm{H} 2$ : Woman directors have a positive effect on corporate financial performance.

H3: Narcissism executives have a positive effect on corporate financial performance.

H4: Narcissism executive have a effect on the relationship between corporate reputation and corporate financial performance.

H5: Narcissism executive have a effect on the relationship between the woman director and corporate financial performance

Appendix:-

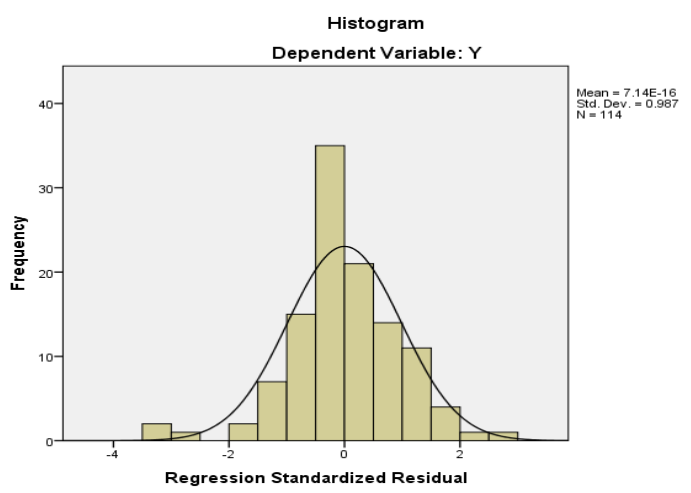

\section{Ujinormalitas:-}

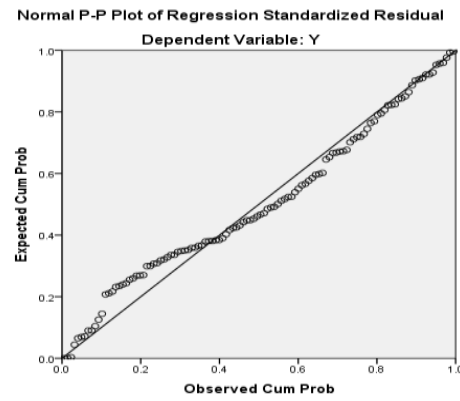

\begin{tabular}{|l|l|l|}
\hline One-Sample Kolmogorov-Smirnov Test & Unstandardized Residual \\
\hline \multicolumn{2}{|l|}{ N } & 114 \\
\hline Normal Parameters ${ }^{\text {a,b }}$ & Mean & .0000000 \\
\cline { 2 - 3 } & Std. Deviation & .51707933 \\
\hline Most Extreme Differences & Absolute & .099 \\
\cline { 2 - 3 } & Positive & .063 \\
\cline { 2 - 3 } & Negative & -.099 \\
\hline Kolmogorov-Smirnov Z & 1.057 \\
\hline Asymp. Sig. (2-tailed) & .213 \\
\hline a. Test distribution is Normal. \\
\hline b. Calculated from data. \\
\hline
\end{tabular}




\section{Uji Heteroskedastisitas:-}

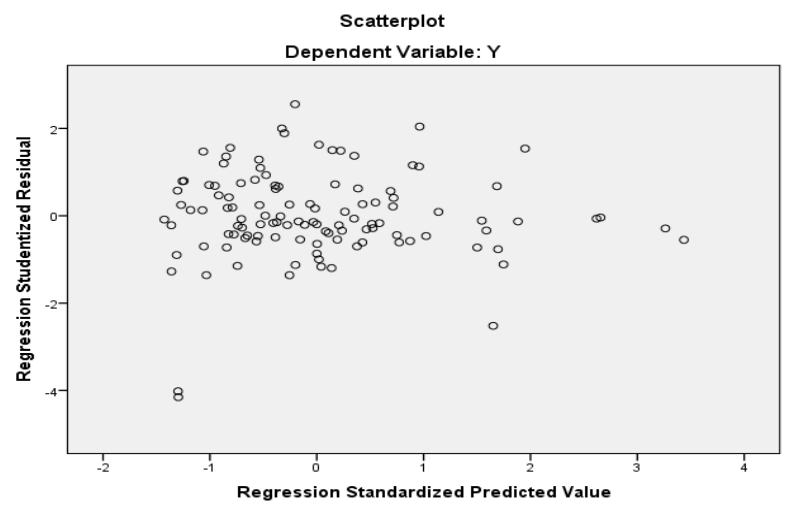

Uji multikolonieritas:-

\begin{tabular}{|l|l|l|l|}
\hline \multirow{2}{*}{ Model } & Collinearity Statistics \\
\cline { 3 - 4 } \multicolumn{2}{|l|}{} & Tolerance & VIF \\
\hline \multirow{4}{*}{1} & (Constant) & & \\
\cline { 2 - 4 } & $\mathrm{X} 1$ & .955 & 1.047 \\
\cline { 2 - 4 } & $\mathrm{X} 2$ & .881 & 1.135 \\
\cline { 2 - 4 } & $\mathrm{M}$ & .921 & 1.086 \\
\hline
\end{tabular}

UjiRegresi:-

Figure 1:-Regression Test Results Before Interacting With Moderating Variables

\begin{tabular}{|l|r|r|c|}
\hline \multicolumn{1}{|c|}{ VariabelIndependen } & Koefisien & Sig. & Keterangan \\
\hline Konstanta & 0.947 & & \\
Corporate reputation $(\mathrm{X} 1)$ & 0.221 & 0.014 & Signifikan \\
Woman director $(\mathrm{X} 2)$ & -1.225 & 0.007 & Signifikan \\
Narcissism executive $(\mathrm{M})$ & 0.007 & 0.003 & Signifikan \\
\hline$\alpha=5 \%=0.05$ & & \\
$\mathrm{R}$ square $=0.238$ atau $23,8 \%$ & & \\
\hline
\end{tabular}

Figure 2:-aRegression Test Results After Interacting with Moderating Variables

\begin{tabular}{|l|c|c|c|}
\hline \multicolumn{1}{|c|}{ VariabelIndependen } & Koefisien & Sig. & Keterangan \\
\hline Konstanta & 0.995 & 0.000 & TidakSignifikan \\
Corporate reputation $(\mathrm{X} 1)$ & 0.095 & 0.408 & Signifikan \\
Interaksi (X1.M) & 0.003 & 0.007 & \\
\hline$\alpha=5 \%=0.05$ & & \\
$\mathrm{R}$ square $=0.134$ &
\end{tabular}

Figure 2:-bRegression Test Results After Interacting with Moderating Variables

\begin{tabular}{|l|r|r|r|}
\hline \multicolumn{1}{|c|}{ VariabelIndependen } & \multicolumn{1}{|c|}{ Koefisien. } & Sig. & Keterangan \\
\hline Konstanta & 1.723 & 0.000 & Signifikan \\
Woman director $(\mathrm{X} 2)$ & -2.930 & 0.000 & Signifikan \\
Interaksi2 $(\mathrm{X} 2 . \mathrm{M})$ & 0.032 & 0.001 & \\
\hline$\alpha=5 \%=0.05$ & & & \\
R square $=0.214$ &
\end{tabular}




\section{Methodology:-}

This study uses a quantitative research approach that aims to determine the extent of the influence of corporate reputation and woman director on corporate financial performance moderated by narcissism executive. The population in this study are all companies listed on the Indonesia Stock Exchange during 2015-2017. The sample selection technique used is non-probability with sampling based on criteria (purposive sampling), that is (1) companies listed on the Indonesia Stock Exchange (IDX) and issuing annual reports during 2015-2017, (2) companies that have excellent results on the Indonesian Corporate Image Award, and (3) companies that have complete data needed in this study. The analysis technique uses multiple linear regression analysis expressed in a relationship between corporate reputation and woman director on corporate financial performance moderated by narcissism executive.

The corporate reputation variable in this study will assessed using data from the Indonesian Corporate Image Award (IMAC) that is proxied by the Corporate Image Index-CII developed by Pramuna and Raharja, (2013) Corporate image provided on the basis of the survey conducted on the respondent group, that is management or business people ,Stockholders or investors, journalists other than infotainment journalists and the public. Woman director is measured by comparing the number of board of directors and commissioners with the total number of board of directors and commissioners in the company. Furthermore, the executive narcissistic variable is measured by looking at the size and number of photos of the board of directors and commissioners in the company's annual report developed by Olsen (2011). Meanwhile, the corporate financial performance variable is measured by the value of ROA, ROE, and EPS in the company.

\section{Results and Discussions:-}

The first thing to do when analyzing the results of this study is to conduct a data normality test. The results of the normality test indicate that the test value of the Kolomogrov-Smirnov column shows that the value asymp significant is 0.213 and the P-Plot diagram shows the points following the diagonal line (appendix 1), so that the results of normality testing can concluded that the data of this study can said to be normal. The results of multikolinearitas testing also showed that there was no multicolinearitas of the data in this study. This is indicated by the values of corporate reputation, woman director, and narcissism executive amounting to 1,047, 1,135, and 1,086 and for the results ofheteroscedasticity testing can seen in appendix 2 .

After testing the quality of the data, the next step is to test the hypothesis. In the study there are two test results, that is the results of regression tests before interacting with moderating variables and regression test results after interacting with moderating variables. The following is an explanation of the regression test results before interacting with the moderating variables that can seen in figure 1 . The first test is done by testing corporate reputation variables on the corporate financial performance. The test results show that there is a significant relationship with a coefficient of 0.221 and a significance level of 0.014 . These results indicate that $\mathrm{H}_{1}$ is accepted. The next test is to examine the relationship between the woman director to the corporate financial performance. The test results show a coefficient of -1.225 with a significant level of 0.007 indicating that $\mathrm{H}_{2}$ is not accepted. The last test is to examine the relationship between narcissism executive to the corporate financial performance. The test results show a coefficient of 0.007 with a significant level of 0.003 which means that $\mathrm{H}_{3}$ is accepted.

Furthermore, regression testing after interacting with moderating variables can seen from figure 2a. Regression test results regarding the interaction between corporate reputation and narcissism executive on financial performance show a significant level of 0.07 and a coefficient of 0.003 which is positive, so it can be concluded that the interaction between narcissism executive can moderate the effects of corporate reputation on corporate financial performance. These results indicate that $\mathrm{H}_{4}$ is accepted.

Whereas the relationship between the interaction between woman director and narcissism executive towards the corporate financial performance can be seen from figure $2 \mathrm{~b}$. The regression test results regarding the interaction between the woman director and narcissism executive towards the corporate financial performance show a significant level of 0.001 with a coefficient of 0.032 . Positive coefficient results indicate that narcissism executive can moderate between the effects of woman director on corporate financial performance. These results indicate that $\mathrm{H}_{5}$ is accepted. 


\section{Discussion:-}

Based on the results of testing the hypothesis above it can be seen that corporate reputation is positively related to the corporate financial performance. These results prove that reputation is one of the important things that must be considered by companies because companies that have a good reputation will have an impact on the corporate financial performance. This means that, the higher corporate reputation, the corporate financial performance also increases. The results of this study are in accordance with the signaling theory which emphasizes that the company intentionally gives a signal to the market which the market is expected to react to and influence the company's stock price which later will also affect the corporate financial performance. In this case, the reputation is a signal sent by the company to get a good response from the market. Therefore, companies that have a good reputation will have an impact on improving the corporate financial performance. The results of this study are in line with several previous studies such as Lee and Jungbae (2012) and Robert and Grahame (2002) which show that companies with a relatively good reputation are able to maintain superior earnings results over time.

While for hypothesis testing shows that the second hypothesis is not accepted. This is because the results of the testing show that the relationship of the woman director has a negative effect on the company's financial performance. This means that the fewer female directors and commissioners in the company, the better the financial performance. The results of this study contradict the resource dependency theory which states that the diversity of the board will provide various benefits of resources for the company (Hillman, et al. 2000). This can be caused by greater gender diversity among members of the board of directors and commissioners producing more opinions and critical questions so that there is more conflict (Lau and Murnighan, 1998), and if there is a conflict management decisions will be more time-consuming and less effective. This research is in line with Dobbin and Jung (2011) and Haslam, et al. (2010) who found a negative relationship between woman directors and market-based performance measured using Tobin's Q.

The results of hypothesis testing indicate that the proposed hypothesis 3 is accepted. This proves that in this case the executive board of directors and commissioners who have narcissism has a positive impact on the corporate financial performance seen from the positive coefficient of narcissism variable. This means that the higher the level of narcissism executive, the higher the corporate financial performance. The results of this study are in line with Maslow's motivational theory, especially at the level of self-actualization which explains the need for selffulfillment. In this study, the board of directors and commissioners are considered to have reached the level of selfactualization because they are at the peak of management. A narcissist will try to do his best to get attention, praise and applause accompanying him. This will ultimately have an impact on the corporate financial performance because the board of directors and commissioners will try their best to manage the company which will be reflected in the corporate financial statements. The results of this study are supported by previous studies, that is Olsen (2011) and Chatterjee and Hambrick (2007) who found a positive relationship between CEO narcissism of the corporate financial performance.

The results of hypothesis testing indicate that the proposed hypothesis 4 is accepted. This finding shows that narcissism executive can significantly strengthen the influence of corporate reputation on the corporate financial performance. These results prove that the board of directors and commissioners who have a high narcissistic nature will optimize themselves to display a good corporate reputation which will later have an impact on the corporate financial performance. Companies that have a good reputation will also have an impact on the reputation of the people inside the company, especially leaders such as the company's board of directors and commissioners. So that in the end it will have an impact on the corporate financial performance.

While the results of hypothesis testing indicate that the proposed hypothesis 5 is accepted. Therefore, the hypothesis that narcissism executive can moderate the influence of the woman director on the corporate financial performance can be empirically proven. This is different from the findings of the previous hypothesis which shows that the direct relationship between the woman director of the corporate financial performance has a positive effect. However, if the influence of the woman director on the corporate financial performance is moderated by narcissism executive, it will have a positive effect. This means that the woman director who has narcissism will have an impact on the corporate financial performance. As far as the researchers' knowledge, there is no literature or other research specifically discussing the relationship between narcissism executive and moderating the relationship between corporate reputation and financial performance and the relationship between narcissism executives moderates the relationship of the woman director to the corporate financial performance. However, at least this research has indicated a moderating relationship and can be the basis for further research. 


\section{Conclusions and Recommendations:-}

The results of this study indicate that of the five existing hypotheses, there are four accepted hypotheses and one hypothesis that is not accepted. The relationship between corporate reputation and narcissism executive has a positive effect on the corporate financial performance. While the woman director has a negative effect on the corporate financial performance. However, after the woman director and narcissism executive interact can have a positive effect on the corporate financial performance, as well as the interaction relationship between corporate reputation and narcissism executive has a positive influence on the corporate financial performance. These results indicate that the corporate reputation is an important thing that must be considered by the company to support the corporate financial performance. Likewise with the narcissistic nature that needs to be owned by the board of directors and commissioners to be able to improve the corporate financial performance. However, the woman director in the sample company had a negative impact on the corporate financial performance. Except if the woman director who has narcissistic nature will have a positive impact on the company's financial performance. Likewise with companies that have reputation and narcissism executives, it will have a better impact on the corporate financial performance.

The results of this study can provide implications for companies and investors, especially regarding corporate reputation and woman director on corporate financial performance moderated by narcissism executive. This research empirically can be used as reference material for policy making and decisions by company management and investors. This research was carried out due to the limitations that could reduce the quality of the results of the research, thus affecting the results of the study. Then it is expected that in future studies it can consider some of the suggestions put forward by researchers, namely the expansion of years of observation can done so that the results of the study are stronger to explain the relationship of influence and accuracy of the results of research and use other variables that might be factors that influence corporate financial performance.

\section{References:-}

1. Abdullah Shamsul N., Ku Nor Izah Ku Ismail dan Lilac nachum. 2015. Does Having Women on Boards Create Value? The Impact of Societal Perceptions and Corporate Governance in Emerging Markets. Strategic Management Journal.

2. Adams, R., dan Ferreira, D., 2009. Women in the Boardroom and their Impact on Governance and Performance. Journal of Financial Economics.

3. Akerlof, George A. 1970. The Market for "Lemon": Quality Uncertainty and the Market Mechanism. The Quarterly Journal of Economics, Vol. 84, No.3.

4. Anderson, R. C., Reeb, D. M., Upadhyay, A., dan Zhao, W. 2011. The economics of director heterogeneity. Financial Management.

5. Amernic, Joel H. dan Craig, Russell J. 2010. Accounting as a Facilitator of Extreme Narcissism. Journal of Business Ethics.

6. Carmeli, A. dan Tishler, A. 2005. Perceived Corporate reputation and Organizational Performance: An Empirical Investigation of Industrial Enterprises.Corporate Reputation Review.Vol. 8

7. Carter, D. A., Simkins, B. J. dan Simpson, W. G. 2003. Corporate Governance, Board Diversity and Firm Value. The Financial Review.

8. Chatterjee, Arijit dan Donald C. Hambrick. 2007. It's All About Me: Narcissistic CEOs and Their Effects on Company Strategy and Performance. Administrative Science Quarterly

9. Daniels, Michael. 1982. The Development of the Concept of Self-actualization in the writing of Abraham Maslow. Current Psychological Reviews.

10. Dargnies MP. 2012. Men Too Sometimes Shy Away from Competition: The Case of Team Competition. Management Science.

11. [Dobbin, F. dan Jung, J. 2011. Corporate Board Gender Diversity and Stock Performance: The Competence Gap or Institutional Investor Bias? North Carolina Law Review.

12. Dunn JR dan Schweitzer ME. 2005. Feeling and Believing: the Influence of Emotion on Trust. J PersSoc Psychol. 88(5):736-48.

13. Eberl, M., danSchwaiger, M. 2005. Corporate Reputation: Disentangling The Effects On Financial Performance. European Journal of Marketing.

14. Fitra, Safrezi.2014. KinerjaMenurun, SahamEmitenPakanTernakAnjlok. (Online). Accessed on 4 November 2014. https://katadata.co.id/berita/2014/11/04/kinerja-menurun-saham-emiten-pakan-ternak-anjlok 
15. Haslam, S.A., Ryan, M.K., Kulich, C., Trojanowski, G. dan Atkins, C. 2010. "Investing with prejudice: the relationship between women's presence on company boards and objective and subjective measures of company performance". British Journal of Management, Vol. 21 No. 2.

16. Hillman, A. J., Shropshire, C., danCannella, A. A. 2007. Organizational predictors of women on corporate boards. Academy of Management Journal.

17. Huang, J., danKisgen, D.J. 2013. Gender and corporate finance: Are male executives overconfident relative to female executives?.Journal of Financial Economic.

18. Judge, T. A., Piccolo, R. F. danKosalka, T. 2009. The bright and dark sides of leader traits: a review and theoretical extension of the leader trait paradigm. Leadership Quarterly.

19. Kets de Vriesdan Manfred F.R. 1994. The Leadership Mystique.Academy of Management Executive.

20. Kitchen, Philip J., dan Andrew Laurence. 2003. Corporate Reputation: An Eight-Country Analysis. Corporate Reputation Review, Vol.6, No.2.

21. Lee, Joohdan James JungbaeRoh. 2012. Revisiting corporate reputation and firm performance link. Benchmarking: An International Journal Vol. 19.

22. Lubit R. 2002. The long-term organizational impact of destructively narcissistic managers. Academy of Management Executive

23. Maccoby, M. 2004. The Productive Narcissist: The Promise and Peril of Visionary Leadership. New York: Broadway Books.

24. Maslow, A.H. 1948. Some Theoretical Consequences of Basic Need Gratification. Journal of Personality.

25. Morris, Richard D. 1987. Signalling, Agency Theory and Accounting Policy Choice. Accounting and Business Research, Vo.18, No.69.

26. Mulyadi. 2001. AkuntansiManajemen. SalembaEmpat: Jakarta.

27. Olsen, Kari Joseph. 2011. CEO Narcissism and Accounting: A Picture of Profits. Journal of Management Accounting Research: Fall 2014, Vol. 26, No.2.

28. Pfeffer, J. danSalancik, G. 1978. The external control of organizations: A resource-dependence perspective. New York: Harper and Row.

29. Pramuna, Rachmatikadan Surya Raharja.2013. DampakPengungkapanSumberDayaManusiaterhadapReputasi Perusahaan. Diponegoro Journal of Accounting Vol.2 No.3.

30. Racanti, NiccoloGordini Elisa. 2017. Gender Diversity in the Italian Boardroom and Firm Financial Performance. Management Research Review, Vol. 40.

31. Rindova, V., Williamson, I., Petkova, A., dan Sever, J. 2005. Being good or being known: an empirical examination of the dimensions, antecedents, and consequences of organizational reputation. Academy of Management Journal.

32. Robbins, Stephen P. dan Timothy A. Judge. 2015. PerilakuOrganisasi. SalembaEmpat: Jakarta.

33. Roberts, Peter W. dan Grahame R. Downling. 2002. Corporate Reputation And Sustained Superior Financial Performance. Strategic Management Journal. J.

34. Ross, S. A. 1977. The Determination Of Financial Structure: The Incentive Signaling Structure. Bell Journal of Economics.

35. Smith, N., Smith, V. danVerner, M. 2006. Do women in top management affect firm financial performance? A panel study of 2,500 Danish Firms. International Journal of Productivity and Performance Management.

36. Tarr-Whelan, L. 2009.Women lead the way. Berrett-Koehler Publishers, New York.

37. Terjesen, S., Sealy, R., dan Singh, V. 2009. Women directors on corporate boards: A review and research agenda. Corporate Governance: An International Review.

38. Triana M, Miller T, danTrzebiatowski T. 2014. The double edged nature of board gender diversity: diversity, firm performance, and the power of women directors as predictors of strategic change. Organization Science.

39. Wales, William J., PankajC.Pateldan G.T. Lumpkin. 2013. In Pursuit of Greatness: CEO Narcissism, Entrepreneurial Orientation, and Firm Performance Variance. Journal of Management Studies.

40. Young, S. Mark danPinsky, Drew. 2006. Narcissism and celebrity. Journal of Research in Personality. 